AT-TAJDID: Jurnal Pendidikan Dan Pemikiran Islam

(p-ISSN: 2548-5784 |e-ISSN: 2549-2101)

Vol. (04 ) (02), (Desember) (2020), (Halaman) (125-132)

Doi: http://dx.doi.org/10.24127/att.v4.i02.1348

\title{
AKTUALISASI PENDIDIKAN KARAKTER RELIGIUS UNTUK MEMBENTUK PERILAKU BAIK PESERTA DIDIK DI MADRASAH TSANAWIYAH ASH SHOLIHUDDIN DAMPIT
}

\author{
Alif Achadah ${ }^{1}$ \\ Universitas Islam Raden Rahmat Malang \\ E-mail : achadahalif@gmail.com \\ Muhammad Ilyas ${ }^{2}$ \\ Pondok Pesantren Ash-Sholihuddin Dampit \\ E-mai : muhilyas816@gmail.com
}

\begin{abstract}
ABSTRAK
Pendidikan adalah salah satu aspek yang sangat penting dalam perjalanan perkembangan suatu negara. Terkait dengan hal tersebut adanya lembaga pendidikan mempunyai peran yang sangat penting dalam upaya untuk mencetak dan melahirkan generasi muda yang berintelektual modern serta mempunyai perilkau baik sebagai pedoman dalam pendidikan Islam. Aktualisasi pendidikan karakter sangatlah diperlukan dalam konteks lembaga pendidikan baik di tingkat SD/SMP, maupun SMA bahkan PT. Dalam kajian ini lebih khusus membahas tentang aktualisasi pendidikan karakter dalam bidang keagamaan sebagai upaya untuk membentuk perilaku baik siswa di MTs As-Sholihuddin Dampit. Terkait hal tersebut, dalam riset ini membahas tentang: 1) bagaimana aktualisasi pendidikan karakter religius siswa di MTs AsSholihuddin Dampit, 2) apa saja faktor pendukung dan penghambat penerapan pendidikan karakter religius di MTs As-Sholihuddin Dampit.
\end{abstract}

Kata Kunci: Aktualisasi, karakter, religius

\begin{abstract}
ABSTRAK
Education is one very important aspect in the development journey of a country. In connection with this, the existence of educational institutions has a very important role in the effort to produce and produce young generations who have modern intellectual and good behavior as a guide in Islamic education. Actualization of character education is needed in the context of educational institutions both at the SD / SMP, and SMA and even PT. In this study more specifically discusses the actualization of character education in the religious field as an effort to shape good behavior of students at MTs As-Sholihuddin Dampit. Related to this, this research discusses: 1) how the actualization of student religious character education at MTs As-Sholihuddin Dampit, 2) what are the supporting and inhibiting factors for the application of religious character education at MTs As-Sholihuddin Dampit.
\end{abstract}

Keywords: Actualization, character, religious 


\section{A. PENDAHULUAN}

Saat pemimpin dan masyarakat Indonesia saat itu memutuskan untuk mengumumkan kemeerdekannya pada tanggal 17 Agustus 1945, pada keadaan itu setidaknya terdapat tiga pekerjaan besar yang hendaknya harus dikerjakan usai kemerdekaan Indonesia yaitu: 1) menciptakan negara yang bersatu dan berdaulat, 2) berusaha memperbaiki infrastruktur negara, 3) membangun dan menciptakan kepribadian bangsa. Setidaknya ketiga hal tersebutlah yang menjadi garapan besar dan menjadi konsep negara (nation-state) dan pembangunan karakter bangsa (nation and character building). Penerapannya dalam usaha menciptakan bangsa yang aspek pembangunannya disegala lini dan bidang serta upaya pembentukan karakter bangsa harus dilakukan dengan terus menerus sehingga dapat berjalan berkesinambungan. Sehingga hal tersebut menjadi pedoman kehidupan bagi masyarakat bangsa Indonesia (Samani dan Hariyanto, 2016).

Kondisi masyarakat Indonesia akhirakhir ini memang semakin mengkhawatirkan. Masalah yang cukup serius dihadapi bangsa Indonesia adalah masalah kenakalan remaja. Negara Indonesia sekarang daapat diketahui dan diidentifikasi bahwa mulai terkikisnya perilaku-perilaku normatif yang perilaku tersebut merupakan identitas dari bangsa Indonesia. Sering kita temui perilakuperilaku mneyimpang yang dilakukan oleh generasi muda yang tidak mencerminkan kebudayaan Indonesia seperti demonstrasi yang tidak bertujuan sehingga menimbulkan pertengkaran dan konflik dengan teman atau masyarakat, korupsi yang dilakukan oleh aparatur pemerintah, adanya hukuman yang tidak sepadan antara pelaku kejahatan dengan aparat penegak hukum yang mengakibatkan kepercayaan masyarakat terhadap hukum berkurang. Sehingga tidaklah menjadi hal yang berlebihan ketika adanyaa upaya pendidikan karakter generasi muda menjadi semangat yang tak akan berhenti, di negeri kita hanya sebagai bahan pembicaraan saja, karena figur yang dapat dijadikan rujukan masyarakat dalam mengaktualkan nilai karakter sangatlah sulit untuk ditemukan.

Dalam upaya pembentukan kaarakter ini dimulai dari keluarga sebagai awal pembangunan karakter anak. Tempat lain yang menjadi sangat krusial adalah lembaga pendidikan tempat anak-anak bersekolah dan mencetak generasi muda yang berintelektual tinggi dan berperilaku terpuji. Kenyataannya banyak kenyataan yaang kita temui tidak seperti harapan kita seperti adanya perilaku menyimpang seperti narkoba, pergaulan bebas yang pelakunya adalah pelajjar dan mahasiswa. Sebagaimana hasil survey dari Behavior Survey menyatakan bahwa hampir kotakota besar seperti Jabodetabek, Bandung, Yogyakarta, Surabaya, dan Bali ditemui dan didapatkan hasil dari wawancara bahwa hampir $61 \%$ dari penduduk laki-laki dengan perempuan antara usia 15-25 tahunsudah pernah melakukan free sex ( $\operatorname{sex}$ bebas). Dan yang tidak kalah memperihatinkan adalah bahwa pringking terbanyak yang dicapai dan sudah melakukan sex bebas adalah komunitas mahasiswa yang hampir mencapai $31 \%$ pegawai swasta $18 \%$, sisanya ada pedagang, pembisnis, buruh dan sebagainya, termasuk 6\% siswi Sekolah Menengah Pertama dan Sekolah Menengah Atas (Syarbini, 2017).

Berkaitan dengan hal tersebut pendidikan karakter dianggap sebagai 
solusi penting untuk menyelesaikan berbagai fenomena kerapuhan moral yang terjadi. Pendidikan karakter mempunyai kakhususan yang sangat umum serta beraspek multikasus karena termasuk aspek-aspek yang sampai sekarang dilakukan dan dibangun yang meliputi: 1) pembangunan karakter merupakan sesuatu yang sangat esensi sebagai upaya menumbuhkan dan membangun perilaku generasi muda, 2) pendidikan karakter berfungsi sebagai nahkoda dalam pembentukan perilaku dan norma agar sesuai dengan ciri khas bangsa (Syarbini, 2017). Sikap kepribadian memberi tentang deskripsi atau cerminan tentang suatu negara, yang hal tersebut dapat dinilai sebagai ciri khas dari suatu negara sehingga dapat diidentifikasi sebagai pembeda negara yang satu dengan yang lain. Ketika suatu negara dianggap meju dan berkembang, maka negara terssebut harus mempunyai ciri khas dari kebudayaanya dan berkepribadian sehingga dapat berpengaruh pada perkembangan peradaban sehingga menjadi tolak ukur perkembangan dunia (Muwafik Saleh, 2012).

Dalam kaitanya dengan hal diatas, terdapat beberapa identifikasi dari beberapa norma pembentuk kepribadian berdasarkan pengalaman dari fenomena sosial. Adapun norma-norma yang bersumber dari religius, pancasila, kebudayaan, dan tujuan pendidikan nasional yaitu: 1) agama, 2) kredibel, 3) keterbukaan, 4) tertib, 5) kerja keras, 6) inovatif, 7) independen, 8) demokrasi, 9) keingintahuan, 10) Nasionalisme, 11) Patriotisme, 12) menghargai keberhasilan, 13) informatif, 14) penuh kasih, 15) suka membaca, 16) sosialisasi, 17) afeksi, 18) komitmen (Samani dan Hariyanto, 2016).
Terkait dengan semua hal diatas, terkait bagaimana implementasi pendidikan Karakter religious dalam membentuk Ahlakul Karimah peserta didik di Madrasah Tsanawiyah Ash - Sholihuddin. Peneliti melakukan penelitian di lokasi ini karena Madrasah Tsanawiyah Ash - Sholihuddin berada di naungan Pondok Pesantren, yang seharusnya menjadi pembeda antara sekolah yang tidak berada dibawah naungan Pondok pesantren. Sehingga peneliti ingin melakukan penelitian yang berjudul "Aktualisasi Pendidikan Karakter Religius dalam Membentuk Perilaku Baik Peserta Didikdi Madrasah Tsanawiyah Ash - Sholihuddin .

\section{B. METODE PENELITIAN}

Penelitian ini merupakan jenis penelitian kualitatif yang menggunakan rancangan studi kasus karena adanya pengamatan atau observasi secara mendalam yang dilakukan oleh peneliti. Pengamatan tersebut terkait kegiatan yang ada dalam obyek penelitian. Terkait pendapat Moleong menyebutkan bahwa riset kualitatif merupakan salah satu bentuk riset yang bertujuan untuk mengerti dan faham tentang suatu kenyataan yang dirasakan oleh sumber informasi misalnya terkait anggapan, motivasi, keadaan sosial, dll. Secara garis besar riset kualitatif dapat difahami untuk melukiskan terhadap fenomena yang dialami oleh seorang individu (Moleong, 2011).

Menurut Yin, riset yang menggunakan metode studi kasus bertujuan untuk mengerti dan faham terhadap kuosioner yang berhubungan dengan bagaimana dan mengapa tentang kasus tertentu dan untuk mengontrol kejadian dalam kehidupan riil (Yin, 2014). Riset kualitatif menggunakan konsep studi kasus 
yang dijadikan rujukan karena sumber data yang dikhususkan pada obyek yang akan dilakukan riset. Adapun data yang diperlukan meliputi bagaimana implementasi pendidikan karakter religius untuk membentuk ahlakul karimah peserta didik di Madrasah Tsanawiyah AshSholihuddin.

Sebagai bahan pertimbangan ketika menentukan rumusan masalah dalam riset yaitu adanya kecukupan atau adanya sumber data yang dibutuhkan. Sumber data yang dimaksud yaitu subyek tentang sumber data dihasilkan. Fatchan menyebutkan bahwa jenis data yang bisa digunakan dalam riset kualitatif pada umunya berupa wawancara, perbuatan, serta kegiatan sehari-hari yang dilakukan oleh sumber akan di teliti (Fatchan, 2011).

Adapun dalam proses pengumpulan data, riset kualitatif bisa berupa narasi, gambaran, cerita yang disusun secara rapi sesuai dengan tata bahasa yang baik dan benar yang semua itu didapatkaan dari informasi sumber data atau responde. Terkait dengan hal tersebut, dalam riset kualitatif dalam pengumpulan datanya menggunakan cara observasi, wawancara, dan dokumentasi.

\section{Observasi}

Creswell menyebutkan yakni observasi merupakan teknik pengumpulan data yang pada prakteknya pengkaji atau perintis secara langsung mengamati kegiatan dan aktivitas satu-persatu nara sumber dan obyek penelitian di lokasi penelitian (Creswell, 2010). Proses pengamatan yang dipakai dalam riset ini yaitu pengamatan terstruktur tujuannya agar peneliti merencanakan dengan seksama dan urut terkait masalah yang akan dikaji atau masalah yang menjadi bahan riset. Artinya, peneliti hanya mengamati aktivitas-aktivitas yang relevan sebagai upaya untuk mendapatkan data yang dibutuhkan sehingga permasalahan yang dikemukakan dapat terjawab.

2. Wawancara

Yin menjelaskan tentang salah satu sumber data yang signifikan pada studi kasus adalah interview atau tanya jawab, karena proses interview adalah sebuah proses tanya jawab antara dua orang atau lebih tentang suatu permasalahan (Yin, 2014).

\section{Dokumentasi}

Sugiyono menyatakan tentang dokumen adalah notes kejadian yang telah berlaku, dokumen bisa berbentuk tulisan, gambar, atau karya-karya monumental dari seseorang (Sugiyono, 2010). Penelitian ini menggunakan dokumentasi sebagai data pelengkap atau memperjelas data hasil riset. Dokumen dalam riset ini berupa fotofoto aktivitas riset, video atau rekaman dan transkip interview.

\section{PEMBAHASAN}

1. Aktualisasi pendidikan karakter religius dalam membentuk sikap peserta didik di Madrasah Tsanawiyah Ash Sholihuddin Dampit.

Implementasi pendidikan karakter religus di Madrasah Tsanawiyah Ash Sholihuddin Dampit dirancang dan disesuaikan dengan latarbelakang lingkungan sekolah. Lingkungan Madrasah Tsanawiyah Ash Sholihuddin Dampit yakni beralamat di jalan Pesantren Nomor 72 Desa Sumbersuko, dengan berbasis pondok pesantren yang berada dinaungan Yayasan Ash Sholihuddin. Selain berlatarbelakang lingkungan pesantren, implementasi pendidikan karakter religius di sekolah ini juga melihat dari kondisi peserta didik yang majemuk, artinya sebagian besar peserta 
didiknya adalah bagian dari santri pondok pesantren Ash Sholihuddin.

Modernisasi atau lebih dikenal dengan sebutan zaman now, kondisi akhlak peserta didik sudah mulai terkikis. Degradasi moral dan karakter peserta didik saat ini, diperlukannya kesadaran dan tindak lanjut yang cukup serius, salah satunya melalui kegiatan religius, seperti yang diungkap kepala sekolah Madrasah Tsanawiyah Ash Sholihuddin Dampit.

Implementasi pendidikan karakter religius yang akan diterapkan Madrasah Tsanawiyah Ash Sholihuddin Dampit didasari oleh visi lembaga yakni "terwujudnya lembaga pendidikan dan pelatihan yang mengedepankan keterampilan, kecerdasan, dan profesionalisme yang dilandasi iman dan taqwa".

Ketiga dasar kebijakan yang telah disebutkan, merupakan pedoman serta menjadi tolak ukur untuk mengimplementasikan pendidikan karakter religius dalam membentuk sikap peserta didik di Madrasah Tsanawiyah Ash Sholihuddin Dampit.

Secara umum implementasi pendidikan karakter religius di Madrasah Tsanawiyah Ash Sholihuddin Dampit diselenggarakan agar peserta didik mampu secara mandiri meningkatkan dan menggunakan pengetahuannya, serta menginternalisasi nilai-nilai karakter religius dan akhlak mulia sehingga terwujud dalam perilaku sehari-hari.

Selaras dengan fungsi dan tujuan pendidikan nasional yang tertuang pada pasal 33 UU Sisdiknas, dapat dirinci bahwa tujuan akhir implementasi pendidikan karakter religius di Madrasah Tsanawiyah Ash Sholihuddin Dampit adalah pembentukan karakter peserta didik yang mampu bersaing, beretika, bermoral, sopan santun dan berinteraksi dengan masyarakat yang dilandasi iman dan taqwa.

Dalam konteks visi Madrasah Tsanawiyah Ash Sholihuddin Dampit, pendidikan karakter religius akan mengantarkan peserta didik dengan potensi yang dimilikinya menjadi insaninsan yang beriman dan bertaqwa, serta berakhlak mulia. Pendidikan karakter religius diimplementasikan dengan ibadah, sopan santun dan homat serta tawaduk terhadap guru dan orang tua. Hal ini selaras dengan pernyataan kepala sekolah yakni "Pelaksanaan pendidikan religius yang dilaksanakan di sekolah ini tentunya memliki tujuan yang mulia, yakni; untuk pembentukan dan pengembangan peserta didik sesuai dengan falsafah pancasila".

Implementasi pendidikan karakter religius di Madrasah Tsanawiyah Ash Sholihuddin Dampit terintegrasi dari semua kegiatan baik ekstra maupun intra sekolah (secara terpadu) yang dilibatkan secara alamiah dalam proses belajar. Selain itu, pendidikan karakter religius juga diintegrasikan pada mata pelajaran seperti mata pelajaran PAI dan Ubudiyah.

Kegiatan ekstra kurikuler Madrasah Tsanawiyah Ash Sholihuddin Dambit dibidang religius seperti hadrah. yakni kegiatan sholawat keliling. Kegiatan sholawat keliling ini dilakukan oleh seluruh peserta didik Madrasah Tsanawiyah Ash Sholihuddin Dampit yang dilakukan rutin selama dua bulan sekali. Antusias dan semangat peserta didik dalam kegiatan ini ditunjukkan dengan bergemanya lantunan sholawat nabi. Tujuan dari kegiatan ini adalah untuk menumbuhkan serta meningkatkan sikap peserta didik yang cinta kepada nabi Muhammad SAW. Kegiatan sholawat ini juga sebagai ajang memperat tali silahturahmi antara seluruh peserta didik, guru dan wali murid, karena 
pada dasarnya kegiatan sholawat ini di lakukan di rumah peserta didik secara bergantian.

Berdasarkan hasil analisis data, penilaian karakter religius peserta didik di Madrasah Tsanawiyah Ash Sholihuddin Dampit menggunakan instrumen penilaian melalui observasi dan buku kepribadian peserta didik. Instrumen ini dirasa tepat karena nilai karakter religius merupakan kemampuan afektif peserta didik, yang penilaiannya bukan berwujud angka, tetapi lebih pada deskripsi. Buku kepribadian peserta didik ini digunakan untuk bahan evaluasi, karena didalamnya ada catatan tentang perkembangan peserta didik berupa sikap, perilaku dan tidakan peserta didik sesuai dengan indikator-indikator nilai karakter religius yang ditanamkan sekolah.

Tujuan evaluasi merupakan sasaran akhir dalam serangkaian lembaga-lembaga pendidikan baik itu lembaga pendidikan yang bersifat formal maupun lembaga pendidikan yang bersifat non formal. Evaluasi pendidikan karakter religius di Madrasah Tsanawiyah Ash Sholihuddin Dampit dilaksanakan secara berkala. Artinya evaluasi ini dilakukan saat proses program pendidikan karakter religius maupun di akhir program atau akhir semester. Tujuan dari evaluasi ini adalah untuk memperoleh informasi yang akurat dan obyektif terkait program yang telah dilaksanakan dan sebagai acuan untuk mengetahui efisiensi dan efektifitas dari program pendidikan karakter religius. Informasi tersebut dapat berupa pelaksanaan program, dampak dan hasil yang diperoleh.

Hasil penelitian menunjukkan bahwa menumbuhkan sikap peserta didik melalui pelaksanaan pendidikan karakter religius di Madrasah Tsanawiyah Ash Sholihuddin Dampit sudah berjalan lancar dan sesuai apa yang di harapkan. Hal ini ditunjukkan dengan hikmat, semangat dan antusias peserta didik dalam mengikuti semua program pendidikan religius, seperti saat sholat dhuha, sholawat nariyah, istighosah dan sholawat keliling. Rutinitas kegiatan yang diikuti oleh peserta didik selama di lingkungan sekolah menumbuhkan dan menghasilkan karakter yang positif. Seperti di tunjukkan pada gambar di bawah ini.

Perencanaan yang sedemikian baik, pelaksanaan pendidikan karakter religius yang berjalan sesuai dengan ritme kegiatankegiatan sekolah, maka hasilnya pun juga tidak mengecewakan. Keberhasilan Madrasah Tsanawiyah Ash Sholihuddin Dampit dalam berupaya menanamkan nilainilai karakter religius dapat dirasakan oleh para guru, orang tua peserta didik dan terutama yang lebih obyektif adalah masyarakat yang merasakan langsung perilaku para peserta didik.

2. Faktor-faktor yang mendukung dan menghambat aktualisasi pendidikan karakter religius dalam membentuk sikap peserta didik di Madrasah Tsanawiyah Ash Sholihuddin Dampit.

Fasilitas yang mendukung dalam kegiatan implementasi pendidikan karakter religius di Madrasah Tsanawiyah Ash Sholihuddin Dampit ini adalah adanya musholla dan tempat bersuci.

Selain sarana prasarana yang mendukung, SDM yang dimiliki Madrasah Tsanawiyah Ash Sholihuddin Dampit yakni guru PAI serta Ubudiyah juga menjadi potensi atau nilai lebih terhadap implementasi pendidikan karakter religius. Guru PAI serta Ubudiyah selain lulusan dari sarjana juga lulusan dari pondok pesantren. Faktor yang menjadi penghambat dalam implementasi karakter religius ini adalah latar belakang peserta didik yang majemuk. Artinya tidak semua 
peserta didik dapat mudah menginternalisasikan pendidikan karakter religius karena sebagian besar adalah bukan dari bagian santri Ash Sholihuddin. Hambatan lain dalam pelaksanaan pendidikan karakter religius ini adalah Kesiswaan kurang koordinasi dengan dewan guru sehingga mengakibatkan miss comunication guru dan peserta didik.

\section{KESIMPULAN}

Berdasarkan pembahasan yang telah diuraikan di atas, maka peneliti menyimpulkan:

1. Konsep pendidikan karakter religius untuk membentuk ahlakul karimah peserta didik Madrasah Tsanawiyah Ash Sholihuddin Dampit. Konsep implementasi pendidikan karakter religius berdasarkan rapat kerja semua unsur pendidikan Madrasah Tsanawiyah Ash Sholihuddin Dampit yang di lakukan sebelum awal semester baru/ganjil. Perencanaan pendidikan karakter religius secara musyawarah antara stakeholder Yayasan Ash Sholihuddin, yakni komite sekolah, kepala sekolah dan dewan guru serta Bapak/Ibu wali murid adalah langkah awal sebelum implementasi pendidikan karakter religius di Madrasah Tsanawiyah Ash Sholihuddin Dampit. Penyusunan program pendidikan karakter religius dilakukan dengan dasar perencanaan analisis lingkungan sekolah yang berbasis pesantren.

2. Implementasi pendidikan karakter religius untuk membentuk ahlakul karimah peserta didik Madrasah Tsanawiyah Ash Sholihuddin Dampit. Implementasi pendidikan karakter religius di Madrasah Tsanawiyah Ash Sholihuddin Dampit terintegrasi dari semua kegiatan baik ekstra maupun intra sekolah (secara terpadu) yang dilibatkan secara alamiah dalam proses belajar. Implementasi pendidikan karakter religius di Madrasah Tsanawiyah Ash Sholihuddin Dampit dilakukan melalui strategi. 1) strategi inklusif, yakni menginternalisasikan pendidikan karakter religius ke dalam mata pelajaranseperti PAI dan Ubudiyah. 2) selanjutnya dengan strategi budaya sekolah yakni berbasis pesantren. Program pendidikan karakter religius tersebut adalah; kegiatan pra KBM yakni sholat dhuha berjamaah yang dilanjutkan dengan istighosah, berdo'a sebelum dan sesudah belajar, pembacaan sholawat nariyah, pembacaan asmaul husna, sedekah jariyah di setiap hari jum'at, dan sholawat keliling setiap dua bulan sekali. Fasilitas yang mendukung dalam kegiatan implementasi pendidikan karakter religius adalah adanya musholla dan tempat bersuci. Selain fasilitas tersebut, bapak/ibu dewan guru yang perannya sebagai implementator juga merupakan kunci utama yang mendukung program ini, karena memberikan suri tauladan kepada peserta didik Madrasah Tsanawiyah Ash Sholihuddin Dampit. Hal yang menjadi penghambat dalam implementasi pendidikan karakter religius ini kurangnya kesolidan antar semua komponen terutama guru dan peserta didik sehingga mudah terjadi miss comucication pada beberapa kegiatan.

\section{E. DAFTAR PUSTAKA}

Creswell,J.W. (2010). Research Design: Pendekatan Kualitatif, Kuantitatif, 
dan Mixed. Yogyakarta: Pustaka Belajar.

Fatchan, H. A. (2011). Metode Penelitian Kualitatif Beserta Contohnya Proposal Skripsi, Thesis, dan Disertasi (Susilo, S. HM. Ed). Surabaya: Jenggala Pustaka Utama.

Moleong, L. J. (2011). Metode Penelitian Kualitatif. Bandung: PT Raja Grafindo Persada.

Moleong, L. J. (2011). Metode Penelitian Kualitatif. Bandung: PT Raja Grafindo Persada.

Saleh, Akhmad Muwafik. (2012). Pendidikan Karakter dalam Perspektif Spiritual. Malang: Aditya Media Publishing.

Samani, Muchlas \& Hariyanto. 2016. Pendidikan Karakter. Bandung: Remaja Rosdakarya.

Sugiyono. (2010). Metode Penelitian Pendidikan: Pendekatan Kuantitatif, Kualitatif, dan $R \& D$. Bandung: Alfabeta.

Syarbini. Amirulloh. (2017). Pendidikan Karakter Berbasis Keluarga.Cet. Ke1. Yogyakarta: Ar Ruzz.

Yin, R. K. (2014). Studi Kasus Desain \& Metode. Jakarta: PT Raja Grafindo Persada. 